\title{
Frequency of Anaemia in Patients with Musculoskeletal Pain
}

\author{
Kas-iskelet Sistemi Ağrısı Olan Hastalarda Anemi Görülme Sıklığı \\ (D) Fatih Baygutalp, (D) Ayhan Kul
}

Atatürk University Faculty of Medicine, Department of Physical Therapy and Rehabilitation, Erzurum, Turkey

\section{Abstract}

Objective: This study aimed to determine the frequency of anaemia in patients with musculoskeletal pain who were admitted to our clinic. Materials and Methods: Three hundred and thirty-eight patients with musclosketal pain were divided into 2 groups as follows: Group 1 , with diffuse pain, and group 2, with local pain. Serum iron, ferritin, total iron-binding capacity, vitamin B12 and plasma haemoglobin levels were analysed retrospectively.

Results: Patients with iron deficiency and iron-deficiency anaemia were evaluated retrospectively. There was iron deficiency in $35.7 \%$ of all patients with musculoskeletal pain and iron-deficiency anaemia in $11.2 \%$ of all patients. Iron deficiency was identified in both groups when the patients were evaluated separately according to the painful area. The rates of iron deficiency in the groups were $28.3 \%$ in the diffuse pain group and $37.1 \%$ in the local pain group.

Conclusion: We suggest that serum iron and ferritin levels should be measured, and if necessary, supplemented for better treatment success in patients with musculoskeletal pain.

Keywords: Anaemia, frequency, musculoskeletal diseases

\section{Öz}

Amaç: Bu çalışmada kliniğimize kas-iskelet sistemi ağıısı şikayeti ile başvuran hastalarda görülen anemi sıklığının belirlenmesi amaçlandı.

Gereç ve Yöntem: İskelet-kas sistemi ağrısı olan 338 hasta grup 1 (yaygın ağıı) ve grup 2 (lokal ağı) olmak üzere 2 gruba ayrıldı. Hastaların serum demir, ferritin, total demir bağlama kapasitesi, vitamin B12 ve plazma hemoglobin düzeyleri geriye dönük olarak analiz edildi.

Bulgular: Demir eksikliği ve demir eksikliği anemisi olan hastalar geriye dönük olarak değerlendirildi. Kas-iskelet sistemi ağrısı olan tüm hastaların \%35,7'sinde demir eksikliği, \%11,2'sinde demir eksikliği anemisi vardı. Hastalar ağrı bölgesine göre ayrı ayrı değerlendirildiğinde her iki grupta da demir eksikliği olduğu görüldü. Demir eksikliği oranları yaygın ağrı grubunda \%28,3 ve lokal ağrı grubunda \%37,1 olarak saptandı. Sonuç: Kas-iskelet sistemi ağrısı olan hastalarda serum demir ve ferritin düzeylerinin ölçülmesini ve tedavi başarısının artırıması için gerekirse tedavi edilmesini öneriyoruz.

Anahtar kelimeler: Anemi, kas-iskelet sistemi hastalıkları, sıklık

\section{Introduction}

Musculoskeletal disorders are painful conditions and lead to disability. Musculoskeletal system diseases are a group of diseases that may have different causes in terms of pathophysiology, but common characteristics are pain and impaired physical function. The prevalence of musculoskeletal system diseases is high worldwide. World Health Organization (WHO) reports that $1 / 3$ to $1 / 5$ people (including children) have musculoskeletal diseases in a period of their lives (1).

Iron is an important element for almost all life. Nearly twothirds of the iron involves to the structure of heme and as it is well known the oxygen transport function of hemoglobin in erythrocytes is essential. Additionally, some other proteins containing heme such as myoglobin, cytochrome P450, and the cytochromes $a, b$, and c have key roles on mitochondrial respiration and adenosine triphosphate synthesis (2).

Iron-deficiency and iron-deficiency anemia are both common though preventable nutritional problems not only in Turkey but also all over the world (3). Determining iron deficiency, particularly before iron-deficiency anemia develops, is very important for the success of treatment. For this purpose, ferritin is used as a reliable marker of iron storage. It has been shown that ferritin is the most valuable test for the detection and follow-up of iron deficiency. Measurement of serum ferritin 
levels is useful for the treatment of iron-deficiency before the development of anemia (4).

Normal iron function and hemostasis have crucial importance for the normal function of the central nervous system due to the role of iron having a cofactor role in the function of many enzymes involved in neurotransmitter synthesis such as serotonin, norepinephrine, and dopamine (5). Decreased synthesis of these neurotransmitters may take part in pain generation, particularly in neuropathic pain generation (6).

There are very few studies investigating the possible relationship between iron-deficiency and pain. One experimental animal study has demonstrated that iron-deficiency increases acute and chronic pain responses in mice (7). One clinical study with a small sample size has shown that serum ferritin levels are significantly lower in patients with chronic neck pain compared to healthy controls (8).

The lack of a comprehensive descriptive study in the literature investigating the possible association between anemia in a wide range of muscoloskletal pain conditions prompted us to perform this study.

This study aimed to determine anemia frequency of patients who have musculoskeletal system pain, retrospectively.

\section{Materials and Methods}

Five hundred and fifty patients suffering from musculoskeletal pain admitted to Physical Medicine and Rehabilitation outpatient clinic of our hospital within the last five years (between January 1, 2014 and December 1, 2018) were analyzed retrospectively using hospital automation system and patient file archives.

The inclusion criteria were as follows:

1. Patients with musculoskeletal pain

2. Patients who have test results of serum ferritin, iron, vitamin B12 concentrations, total iron-binding capacity (TIBC) and plasma hemoglobin levels.

The exclusion criteria were as follows:

1. Acute and chronic infections (since ferritin is an acute phase reactant)

2. Inflammatory diseases

3. Rheumatic diseases

4. Malignancies

5. Depression

6. Pregnancy and breastfeeding

After the inclusion and exclusion criteria were applied, the study was completed with the data of the remaining 338 patients divided into 2 groups as follows:

\section{Group 1: Diffuse pain}

Group 2: Local pain (artralgia, upper extremity pain, lower extremity pain, neuropathic pain, spinal pain)

Demographic data and serum ferritin, iron, TIBC, vitamin B12 levels and plasma hemoglobin levels were recorded.

Serum ferritin levels of less than $15 \mathrm{ng} / \mathrm{dL}$ were evaluated as iron deficiency. In addition to iron deficiency, patients with hemoglobin values below $12 \mathrm{~g} / \mathrm{dL}$ in premenopausal women and $13 \mathrm{~g} / \mathrm{dL}$ in postmenopausal women and men were evaluated as iron-deficiency anemia (9). Serum total vitamin B12 concentrations of less than $300 \mathrm{pg} / \mathrm{mL}$ values were evaluated as vitamin B12 deficiency and less than 200 pg/ $\mathrm{mL}$ values were evaluated as vitamin B12 insufficiency (10). In our laboratory, the reference range of serum iron level is 37-145 $\mathrm{ug} / \mathrm{dL}$ and the reference range of serum TIBC level is $127-450(\mathrm{pg} / \mathrm{dL})$. A classification was made by applying these criteria and patients were identified as follows: patients with iron deficiency, patients with iron-deficiency anemia, patients with vitamin B12 deficiency, patients with vitamin B12 insufficiency, iron level under the reference range and TIBC level outside the reference range.

\section{Ethical Issues}

The study met the approval of Turkish Statistical Institute (with authorization number 23.08.2019/19496) and the approval of Atatürk University Faculty of Medicine Local Clinical Research Ethics Committee (approval date: 26.09.2019, decision no: 423).

\section{Statistical Analysis}

The results were evaluated in SPSS 23 package program. Descriptive statistics (mean, standard deviation, frequency) were made. Independent samples t-test was performed to determine the difference of age and biochemical parameters between independent groups (comparison of group 1-group 2 and comparison of male-female in all patients, in group 1 and in group 2). $\mathrm{P}<0.05$ values were accepted as statistically significant in a $95 \%$ confidence interval.

\section{Results}

The ages and biochemical parameters of all musculoskeletal pain patients and of the patients divided into 2 groups were demonstrated in Table 1, Table 2 and Figure 1.

The mean age of all patients was $44.7 \pm 14.4$ years, and there was no statistically significant difference between the ages of male and female patients $(p<0.05)$.

\begin{tabular}{|c|c|c|c|}
\hline & $\begin{array}{l}\text { Diffuse pain } \\
(n=53)\end{array}$ & $\begin{array}{l}\text { Local pain } \\
(n=285)\end{array}$ & $\begin{array}{l}\text { p } \\
\text { (Diffuse } \\
\text { pain- local } \\
\text { pain) }\end{array}$ \\
\hline Age (year) & $43.8 \pm 14.4$ & $44.9 \pm 14.4$ & 0.619 \\
\hline $\begin{array}{l}\text { Hemoglobin } \\
(g / d L)\end{array}$ & $13.5 \pm 1.5$ & $14 \pm 7.6$ & 0.681 \\
\hline Iron (ug/dL) & $73.9 \pm 32.5$ & $71.4 \pm 31.9$ & 0.602 \\
\hline Ferritin $(\mathrm{ng} / \mathrm{mL})$ & $44.2 \pm 41.5$ & $37.8 \pm 39.4$ & 0.287 \\
\hline TIBC (pg/dL) & $287.8 \pm 89$ & $288.8 \pm 91.8$ & 0.941 \\
\hline $\begin{array}{l}\text { Vitamin B12 } \\
(\mathrm{pg} / \mathrm{mL})\end{array}$ & $363.5 \pm 154.3$ & $361 \pm 187$ & 0.925 \\
\hline
\end{tabular}




\begin{tabular}{|c|c|c|c|c|}
\hline All patients & $\begin{array}{l}\text { All patients } \\
(\mathrm{n}=338)\end{array}$ & $\begin{array}{l}\text { Female patients } \\
(n=311)\end{array}$ & $\begin{array}{l}\text { Male patients } \\
(n=27)\end{array}$ & $\begin{array}{l}p \\
\text { (Male-female) }\end{array}$ \\
\hline Age (year) & $44.7 \pm 14.4$ & $45 \pm 14.2$ & $40.9 \pm 16.4$ & 0.151 \\
\hline Hemoglobin (g/dL) & $13.9 \pm 7$ & $13.8 \pm 7.3$ & $15.2 \pm 1.8$ & 0.325 \\
\hline Iron (ug/dL) & $71.8 \pm 32$ & $70.2 \pm 30.6$ & $90.3 \pm 41.6$ & 0.002 \\
\hline Ferritin (ng/mL) & $38.8 \pm 39.7$ & $35.9 \pm 36.7$ & $72.9 \pm 55.4$ & $<0.001$ \\
\hline TIBC (pg/dL) & $288.6 \pm 91.2$ & $292.1 \pm 92.1$ & $248.5 \pm 70.3$ & 0.017 \\
\hline Vitamin B12 (pg/mL) & $361.4 \pm 182.1$ & $358 \pm 160.6$ & $400.2 \pm 347.3$ & 0.249 \\
\hline $\begin{array}{l}\text { Group } 1 \\
\text { (Diffuse pain) }\end{array}$ & $\begin{array}{l}\text { All patients } \\
(n=53)\end{array}$ & $\begin{array}{l}\text { Female patients } \\
(n=47)\end{array}$ & $\begin{array}{l}\text { Male patients } \\
(\mathrm{n}=6)\end{array}$ & $\begin{array}{l}\text { p } \\
\text { (Male-female) }\end{array}$ \\
\hline Age (year) & $43.8 \pm 14.4$ & $44.8 \pm 14.2$ & $35.8 \pm 15.1$ & 0.151 \\
\hline Hemoglobin $(\mathrm{g} / \mathrm{dL})$ & $13.5 \pm 1.5$ & $13.3 \pm 1.4$ & $15.3 \pm 0.9$ & 0.002 \\
\hline Iron (ug/dL) & $73.9 \pm 32.5$ & $68.7 \pm 28.7$ & $114.3 \pm 34.5$ & 0.001 \\
\hline Ferritin $(\mathrm{ng} / \mathrm{mL})$ & $44.2 \pm 41.5$ & $40.5 \pm 40.2$ & $72.6 \pm 44.2$ & 0.075 \\
\hline TIBC (pg/dL) & $287.8 \pm 89$ & $295.3 \pm 91$ & $228.7 \pm 37.2$ & 0.084 \\
\hline Vitamin B12 $(\mathrm{pg} / \mathrm{mL})$ & $363.5 \pm 154.3$ & $362.7 \pm 160.7$ & $370.1 \pm 100.9$ & 0.913 \\
\hline $\begin{array}{l}\text { Group } 2 \\
\text { (Local pain) }\end{array}$ & $\begin{array}{l}\text { All patients } \\
(n=285)\end{array}$ & $\begin{array}{l}\text { Female patients } \\
(n=264)\end{array}$ & $\begin{array}{l}\text { Male patients } \\
(n=21)\end{array}$ & $\begin{array}{l}\text { p } \\
\text { (Male-female) }\end{array}$ \\
\hline Age (year) & $44.9 \pm 14.4$ & $45.1 \pm 14.2$ & $42.3 \pm 16.9$ & 0.403 \\
\hline Hemoglobin $(\mathrm{g} / \mathrm{dL})$ & $14 \pm 7.6$ & $13.9 \pm 7.9$ & $15.2 \pm 2$ & 0.460 \\
\hline Iron (ug/dL) & $71.4 \pm 31.9$ & $70.4 \pm 31$ & $83.4 \pm 41.5$ & 0.073 \\
\hline Ferritin (ng/mL) & $37.8 \pm 39.4$ & $35 \pm 36$ & $73 \pm 59.2$ & $<0.001$ \\
\hline TIBC (pg/dL) & $288.8 \pm 91.8$ & $291.5 \pm 92.5$ & $254.2 \pm 77$ & 0.073 \\
\hline Vitamin B12 $(\mathrm{pg} / \mathrm{mL})$ & $361 \pm 187$ & $357.2 \pm 160.9$ & $408.8 \pm 392.3$ & 0.224 \\
\hline
\end{tabular}

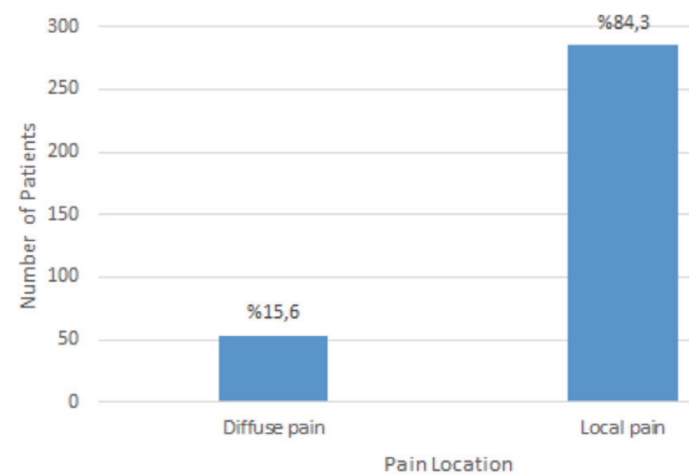

Figure 1. Number and frequency distribution of patients with musculoskeletal pain by pain location

In the independent group comparisons between female and male patients, both serum ferritin and serum iron levels were significantly lower in female patients than in male patients $(p<0.001$ and $p<0.05$, respectively).

Serum TIBC levels were significantly higher in female patients than in male patients $(p=p<0.05)$.

There was no statistically significant difference between serum vitamin B12 levels and plasma hemoglobin levels between male and female patients ( $p>0.05$ for both parameters).

The differences of parameters between pain groups (diffuse pain group and local pain group) were also evalulated with independent samples t-test. There were no significant differences in all parameters (age, hemoglobin, iron, ferritin, TIBC, vitamin B12) between all group comparisons (all group 1 patients-all group 2 patients, female group 1 patients-female group 2 patients, male group 1 patients-male group 2 patients) ( $p>0.05$ for all parameters in all comparisons) (Table 3 ).

Percentages of patients with iron deficiency, iron-deficiency anemia, vitamin B12 deficiency, vitamin B12 deficiency, the iron level below the reference range and TIBC level outside the reference range were determined in all patients and in the patients divided into 2 groups (Table 4, Figures 2, 3).

\section{Discussion}

Our retrospective analysis results have shown that there was iron-deficiency in $35.7 \%$ of all patients with musculoskeletal system pain and iron-deficiency anemia in $11.2 \%$ of all patients. Iron-deficiency was determined in both groups when the patients were evaluated separately according to the pain area. Iron-deficiency rates were determined as follows: in diffuse pain: $28.3 \%$ and in spine pain: $37.1 \%$.

In addition to iron deficiency, iron-deficiency anemia was determined in both groups with the rates $11.7 \%$ in upper 


\begin{tabular}{|c|c|c|c|}
\hline Female and male patients & $\begin{array}{l}\text { Group } 1 \\
\text { (Diffuse pain) }\end{array}$ & $\begin{array}{l}\text { Group } 2 \\
\text { (Local pain) }\end{array}$ & $\begin{array}{l}\text { p } \\
\text { (group 1-group 2) }\end{array}$ \\
\hline Age (year) & $43.8 \pm 14.4$ & $44.9 \pm 14.4$ & 0.619 \\
\hline Hemoglobin $(\mathrm{g} / \mathrm{dL})$ & $13.5 \pm 1.5$ & $14 \pm 7.6$ & 0.681 \\
\hline Iron (ug/dL) & $73.9 \pm 32.5$ & $71.4 \pm 31.9$ & 0.602 \\
\hline Ferritin (ng/mL) & $44.2 \pm 41.5$ & $37.8 \pm 39.4$ & 0.287 \\
\hline TIBC (pg/dL) & $287.8 \pm 89$ & $288.8 \pm 91.8$ & 0.941 \\
\hline Vitamin B12 (pg/mL) & $363.5 \pm 154.3$ & $361 \pm 187$ & 0.925 \\
\hline Female patients & $\begin{array}{l}\text { Group } 1 \\
\text { (Diffuse pain) }\end{array}$ & $\begin{array}{l}\text { Group } 2 \\
\text { (Local pain) }\end{array}$ & $\begin{array}{l}p \\
\text { (group 1-group 2) }\end{array}$ \\
\hline Age (year) & $44.8 \pm 14.2$ & $45.1 \pm 14.2$ & 0.910 \\
\hline Hemoglobin $(\mathrm{g} / \mathrm{dL})$ & $13.3 \pm 1.4$ & $13.9 \pm 7.9$ & 0.629 \\
\hline Iron (ug/dL) & $68.7 \pm 28.7$ & $70.4 \pm 31$ & 0.727 \\
\hline Ferritin (ng/mL) & $40.5 \pm 40.2$ & $35 \pm 36$ & 0.345 \\
\hline TIBC (pg/dL) & $295.3 \pm 91$ & $291.5 \pm 92.5$ & 0.796 \\
\hline Vitamin B12 (pg/mL) & $362.7 \pm 160.7$ & $357.2 \pm 160.9$ & 0.829 \\
\hline Male patients & $\begin{array}{l}\text { Group } 1 \\
\text { (Diffuse pain) }\end{array}$ & $\begin{array}{l}\text { Group } 2 \\
\text { (Local pain) }\end{array}$ & $\begin{array}{l}p \\
\text { (group 1-group 2) }\end{array}$ \\
\hline Age (year) & $35.8 \pm 15.1$ & $42.3 \pm 16.9$ & 0.402 \\
\hline Hemoglobin $(\mathrm{g} / \mathrm{dL})$ & $15.3 \pm 0.9$ & $15.2 \pm 2$ & 0.903 \\
\hline Iron (ug/dL) & $114.3 \pm 34.5$ & $83.4 \pm 41.5$ & 0.110 \\
\hline Ferritin (ng/mL) & $72.6 \pm 44.2$ & $73 \pm 59.2$ & 0.989 \\
\hline $\operatorname{TIBC}(\mathrm{pg} / \mathrm{dL})$ & $228.7 \pm 37.2$ & $254.2 \pm 77$ & 0.444 \\
\hline Vitamin B12 (pg/mL) & $370.1 \pm 100.9$ & $408.8 \pm 392.3$ & 0.815 \\
\hline
\end{tabular}

extremity pain, $11.3 \%$ in diffuse pain and $11.2 \%$ in Icoal pain. Determining iron-deficiency accurately is an important issue for clinicians. For this purpose, measurement of serum ferritin levels is used as a reliable and non-invasive method to indirectly show iron stores of the body and decreased serum ferritin level is considered as a sign of iron depletion (11).

Although there is a wide consensus on the determinative role of ferritin in iron deficiency, different expert organizations recommend various cut-off limits for the diagnosis of iron deficiency. In our study, we used the highly accepted cut-off limit recommended by $\mathrm{WHO}$, which defines iron-deficiency with the ferritin levels less than $15 \mathrm{ng} / \mathrm{dL}$ (9).

However, the concentration of ferrite required to maintain the normal function of muscle tissue and other organs has not been fully established. It has been recommended that, when ferritin levels are below $50 \mathrm{ng} / \mathrm{mL}$, the targeted ferritin concentration in the treatment of iron-deficiency $50 \mathrm{ng} / \mathrm{mL}$ (12).

Iron, a cofactor of the cytochrome oxidase enzyme system, has a vital role in the energy production of muscle. Thus, irondeficiency causes a deterioration in muscle energy production and contributes to the development of muscle fatigue, poor endurance and myofascial pain (13).

An experimental mouse model study has demonstrated that iron-deficiency triggers a reducement in pain threshold and an increment in pain feeling $(7,14)$.

Another perspective for the relationship of iron deficiency and anemia is focused on the role of iron as an essential cofactor of several enzymes which are key elements of neurotransmitter synthesis, particularly tryptophan hydroxylase (in serotonin synthesis) and tyrosine hydroxylase (in norepinephrine and dopamine synthesis) $(5,6)$.

At this point, it is necessary to examine the relationship between serotonin and pain. Serotonin, a neurotransmitter derived from tryptophan, is produced by neurons in the brainstem. Serotonin is broadly circulated throughout the cortex, limbic system, and thalamus by the connections of serotonergic neurons and thus it has inhibitory effects on some pain pathways. There is increasing evidence pointing out the important role of serotonin [5-hydroxytryptamine, (5-HT)] in the modulation of nociceptive transmission. Various 5-HT receptor subtypes have been identified in the central nervous system (15), and in the spinal cord. Experimental studies have shown that $5-\mathrm{HT}$ produces antinociception and several $5-\mathrm{HT}$ receptors take part in the mediation of antinociception (16).

Due to the cofactor role of iron tyrosine hydroxylase enzyme (leading norepinephrine and dopamine synthesis), determining 
Table 4. The incidence of clinical conditions accompanying patients' pain complaints

\begin{tabular}{|c|c|c|c|}
\hline Musculoskeletal pain & $\begin{array}{l}\text { All patients } \\
(n=338) \%\end{array}$ & $\begin{array}{l}\text { Female patients } \\
(n=311) \%\end{array}$ & $\begin{array}{l}\text { Male patients } \\
(n=27) \%\end{array}$ \\
\hline Iron deficiency & 35.7 & 37.6 & 14.8 \\
\hline Iron-deficiency anemia & 11.2 & 11.5 & 7.4 \\
\hline Vitamin B12 deficiency & 43.1 & 42.1 & 55.5 \\
\hline Vitamin B12 insuffuciency & 9.1 & 9.3 & 7.4 \\
\hline Iron level under the ref. range & 12.4 & 12.2 & 14.8 \\
\hline TIBC level outside the ref. range & 5.3 & 5.4 & 3.7 \\
\hline Group 1: Diffuse pain & $\begin{array}{l}\text { All patients } \\
(n=53) \%\end{array}$ & $\begin{array}{l}\text { Female patients } \\
(n=47) \%\end{array}$ & $\begin{array}{l}\text { Male patients } \\
(n=6) \%\end{array}$ \\
\hline Iron deficiency & 28.3 & 29.7 & 16.6 \\
\hline Iron-deficiency anemia & 11.3 & 12.7 & 0 \\
\hline Vitamin B12 deficiency & 37.7 & 38.2 & 33.3 \\
\hline Vitamin B12 insuffuciency & 11.3 & 12.7 & 0 \\
\hline Iron level under the ref range & 16.9 & 19.1 & 0 \\
\hline TIBC level outside the ref. range & 11.3 & 8.5 & 0 \\
\hline Group 2: Local pain & $\begin{array}{l}\text { All patients } \\
(n=285) \%\end{array}$ & $\begin{array}{l}\text { Female patients } \\
(n=264) \%\end{array}$ & $\begin{array}{l}\text { Male patients } \\
(n=21) \%\end{array}$ \\
\hline Iron deficiency & 37.1 & 39 & 14.2 \\
\hline Iron-deficiency anemia & 11.2 & 11.3 & 9.5 \\
\hline Vitamin B12 deficiency & 44.2 & 42.8 & 61.9 \\
\hline Vitamin B12 insuffuciency & 8.7 & 8.7 & 9.5 \\
\hline Iron level under the ref. range & 11.5 & 10.9 & 19 \\
\hline TIBC level outside the reference range & 6.6 & 5.3 & 4.7 \\
\hline
\end{tabular}

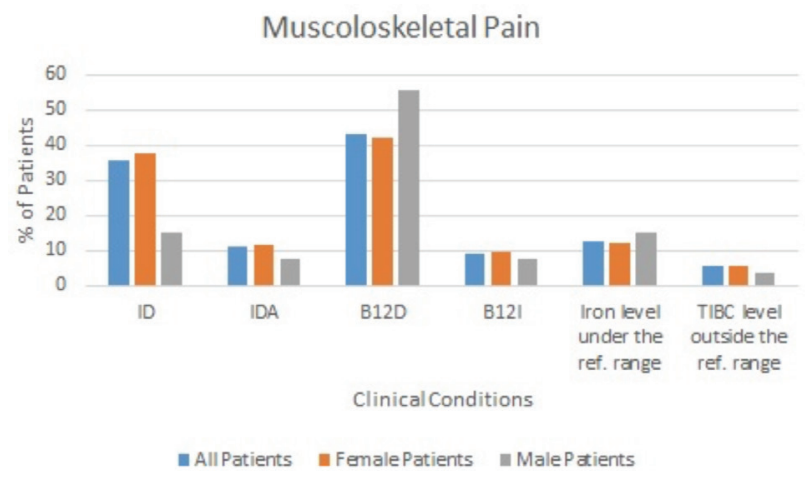

Figure 2. The frequency of clinical conditions associated with pain complaints in patients with musculoskeletal pain

ID; Iron-deficieny, IDA; Iron-deficiency anemia, B12D: Vitamin B12 deficiency, B121: Vitamin B12 insufficiency, ref.:reference, TIBC: Total iron-binding capacity

the possible role of dopaminergic neurotransmission in chronic pain is an important field of interest for researchers.

Dopaminergic neurotransmission is thought to play a pivotal role in moderating pain sensation and analgesia. Researchers reporting decreased dopamine levels in Fibromyalgia syndrome have concluded that abnormal dopaminergic neurotransmission may be responsible for the painful conditions of fibromyalgia and painful diabetic neuropathy. Another evidence supporting the potent relationship between iron, pain sensation and dopaminergic system is the curative effect achieved by using dopamine agonists in Restless Leg syndrome patients (17). Here is an important point is to note that, experimental animal studies have demonstrated that while analgesia is induced by the activation of mesolimbic dopamine neurons by acute stress, chronic stress conditions trigger a reverse effect on pain sensation and lead to hyperalgesia by decreasing mesolimbic dopaminergic output (18).

Although investigating the relationship between pain and Fibromyalgia syndrome is out of the scope of our study, we note that reduced concentration of dopamine, norepinephrine, and serotonin is reported in FMS patients, who have different pain perception from that of the broad population, consequence of degenerated pain processing pathways in the central nervous system $(5,19)$.

An issue must be considered in the planning of a study design investigating ferritin levels is that is the possibility that elevated ferritin levels may be arisen from inflammation conditions because ferritin is an acute-phase reactant. In this study, we excluded patients with inflammatory diseases and rheumatic diseases based on the detailed anamnesis of patients.

The limited studies available in the literature aimed to investigate the possible relationship between iron-deficiency and pain have 

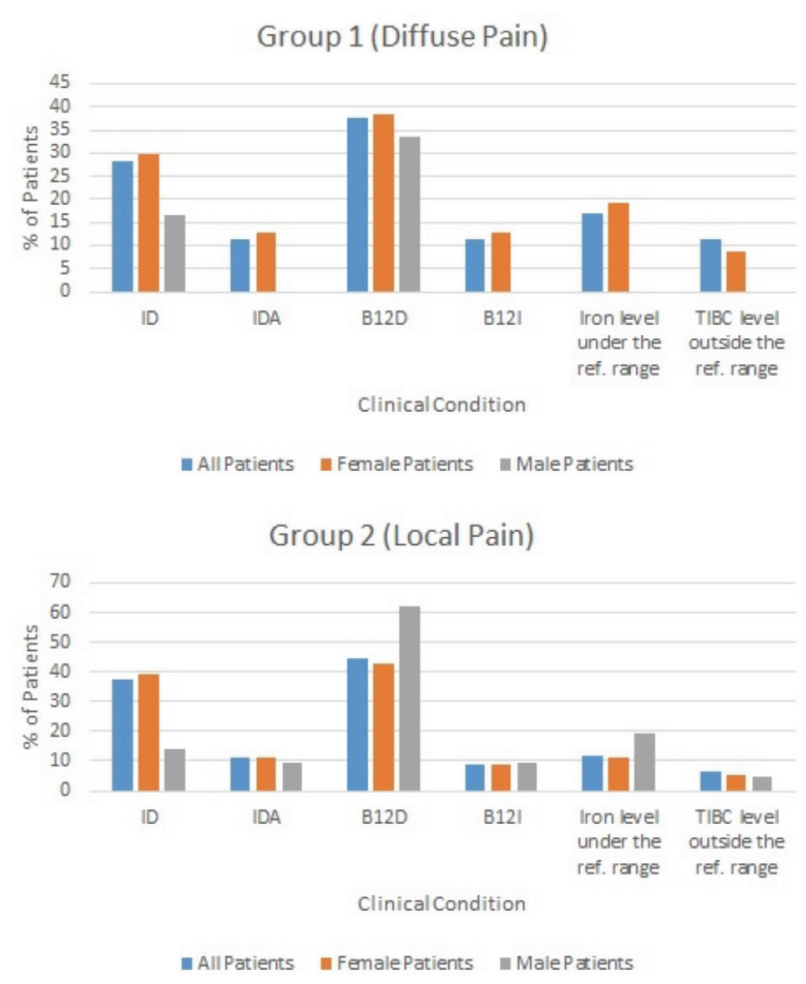

Figure 3. The frequency of clinical conditions accompanying pain complaints in patients with musculoskeletal pain divided into different groups

ID: Iron-deficieny, IDA: Iron-deficiency anemia, B12D: Vitamin B12 deficiency, B121: Vitamin B12 insufficiency, ref:: reference, TIBC: Total iron-binding capacity

small sample sizes (8). Our study was performed with larger sample size.

\section{Study Limitations}

Our study has a limitation with the study design being retrospective.

\section{Conclusion}

To the best of our knowledge, this is the first study in English literature, reporting iron-deficiency and iron-deficiency anemia rates in a large number of sample size in various musculoskeletal system pain conditions. Based on our results, we suggest that serum iron and ferritin levels should be measured and, if necessary, treated to improve treatment success in patients with musculoskeletal system pain.

\section{Ethics}

Ethics Committee Approval: The study met the approval of Turkish Statistical Institute (with authorization number 23.08.2019/19496) and the approval of Atatürk University Faculty of Medicine Local Clinical Research Ethics Committee (approval date: 26.09.2019, decision no: 423).

Informed Consent: Informed consent is not appliciable. Peer-review: Externally and internally peer-reviewed.

\section{Authorship Contributions}

Surgical and Medical Practices: F.B., A.K., Concept: F.B, A.K., Design: F.B., A.K., Data Collection or Processing: F.B, Analysis or Interpretation: F.B., Literature Search: F.B., A.K., Writing: F.B., A.K. Conflict of Interest: No conflict of interest was declared by the authors.

Financial Disclosure: The authors declared that this study received no financial support.

\section{References}

1. Woolf $A D$, Pfleger B. Burden of major musculoskeletal conditions. Bull World Health Organ 2003;81:646-56.

2. Gordon N. Iron-deficiency and the intellect. Brain Dev 2003;25:3-8.

3. Stevens GA, Finucane MM, De-Regil LM, Paciorek CJ, Flaxman SR, Branca F, et al. Nutrition Impact Model Study Group (Anaemia). Global, regional, and national trends in haemoglobin concentration and prevalence of total and severe anaemia in children and pregnant and non-pregnant women for 1995-2011: a systematic analysis of population-representative data. Lancet Glob Health 2013;1:e16-25.

4. Knovich MA, Storey JA, Coffman LG, Torti SV. Ferritin for the Clinician. Blood Rev 2009;23:95-104.

5. Ortancil O, Sanli A, Eryuksel R, Basaran A, Ankarali H. Association between serum ferritin level and fibromyalgia syndrome. Eur J Clin Nutr 2010;64:308-12.

6. Beard JL, Connor JR. Iron status and neural functioning. Annu Rev Nutr 2003;23:41-58.

7. Dowling P, Klinker F, Amaya F, Paulus W, Liebetanz D. Iron-deficiency sensitizes mice to acute pain stimuli and formalin-induced nociception. J Nutr 2009;139:2087-92.

8. Eloqayli H, Al-Yousef A, Jaradat R. Vitamin D and ferritin correlation with chronic neck pain using standard statistics and a novel artificial neural network prediction model. Br J Neurosurg 2018;32:172-6.

9. WHO. Serum ferritin concentrations for the assessment of iron status and iron-deficiency in populations. Vitamin and Mineral Nutrition Information System. Geneva, World Health Organization 2011; WHO/NMH/NHD/MNM/11.2.

10. Sukumar N, Saravanan P. Investigating vitamin B12 deficiency. BMJ 2019;365:11865.

11. Daru J, Colman K, Stanworth SJ, De La Salle B, Wood EM, Pasricha SR. Serum ferritin as an indicator of iron status: what do we need to know? Am J Clin Nutr 2017;106:1634S-1639S.

12. World Health Organization. Nutritional anaemias: tools for effective prevention and control. Geneva: WHO Document Production Services; 2017.

13. Gerwin R. A review of myofascial pain and fibromyalgia-factors that promote their persistence. Acupunct Med 2005;23:121-34.

14. Jeong CY, Choi J, Yoon MH.Roles of serotonin receptor subtypes for the antinociception of $5-\mathrm{HT}$ in the spinal cord of rats. Eur J Pharmacol 2004;502:205-11.

15. Barnes, NM, Shar, T. A review of central 5-HT receptors and their function. Neuropharmacology 1999;38:1083-1152.

16. Jeong CY, Choi J, Yoon MH. Roles of serotonin receptor subtypes for the antinociception of 5-HT in the spinal cord of rats. Eur J Pharmacol 2004;502:205-11.

17. Earley CJ, Allen RP. Pergolide and carbidopa/levodopa treatment of the restless legs syndrome and periodic leg movements in sleep in a consecutive series of patients. Sleep 1996;19:801-10.

18. Wood PB. Stress and dopamine: implications for the pathophysiology of chronic widespread pain. Med Hypotheses 2004;62:420-4.

19. Legangneux E, Mora JJ, Spreux-Varoquaux O, Thorin I, Herrou M, Alvado $G$, et al. Cerebrospinal fluid biogenic amine metabolites, plasma-rich platelet serotonin and [3H] imipramine reuptake in the primary fibromyalgia syndrome. Rheumatology (Oxford) 2001;40:290-6. 